\begin{tabular}{l|l} 
J. Braz. Chem. Soc., Vol. 18, No. 6, 1254-1258, 2007. \\
Printed in Brazil - C2007 Sociedade Brasileira de Química \\
$0103-5053 \$ 6.00+0.00$
\end{tabular}

\title{
Synthesis of Macrocyclic Polyazomethines
}

\author{
Elizbar Elizbarashvili, ${ }^{*}$ Tea Matitaishvili and Khatuna Topuria
}

Department of Organic Chemistry, Georgian Technical University, 77 Kostava Street, Tbilisi, 0175, Georgia

\begin{abstract}
A síntese de corantes macrocíclicos poliazometínicos de 20 membros, poliazometina 3a e $\mathbf{3 b}$, a partir de 4,4'-di-hidroxibifenil-3,3'-di-carbaldeído (2a) e 5,5'-diamino-4,4'-di-hidroxibifenil-3,3'di-carbaldeído (2b) e de pigmentos macrocíclicos poliazometínicos 4 e 5, a partir de $\mathbf{3 a}$ é descrita.
\end{abstract}

The synthesis of 20-membered macrocyclic polyazomethine dyes $\mathbf{3 a}$ and $\mathbf{3 b}$ from 4,4'dihydroxybiphenyl-3,3'-dicarbaldehyde (2a) and 5,5'-diamino-4,4'-dihydroxybiphenyl-3,3'dicarbaldehyde (2b) and macrocyclic polyazomethine pigments $\mathbf{4}$ and $\mathbf{5}$ from $\mathbf{3 a}$ is described.

Keywords: macrocycles, azomethine, schiff base

\section{Introduction}

Azomethines are used as substrates to prepare a large number of industrial and biologically active compounds via ring closure, cycloaddition and condensation reactions between primary amines and aldehydes. ${ }^{1}$ Moreover, azomethines are also known to have biological activities such as antimicrobial, ${ }^{2-5}$ antifungal, ${ }^{4}{ }^{6}$ antitumour ${ }^{7-9}$ and as herbicides. ${ }^{10}$ In industry, they have a wide range of application such as dyes and pigments with luminescent properties. ${ }^{11}$ Azomethines are used as ligands for complexation of metal ions giving the complex compounds of rich physical, chemical and biological properties. ${ }^{12-17}$ For that reason, a huge number of monoand bis-azomethines are described in the articles. Moreover, while abundant information on the reactivity and physical-chemical properties of 5-membered cyclic azomethines (oxazoles) exists, macrocyclic azomethines have not been the subject of many investigations. ${ }^{18-21}$

On the other hand, macrocyclic compounds like crown ethers and cryptands have received much attention in the last few years both in chemistry and in biology. Koriakin and Angelov ${ }^{22}$ prepared two azomethines bearing crown ether moiety with the aim of the synthesis of metalloenzymes.

Thus the synthesis of macrocyclic azomethines, bearing properties of both azomethines and macrocyclic compounds, is very interesting. In the current paper, four novel 20membered cyclic polyazomethines have been synthesized.

*e-mail: elizbarashvili@gtu.ge

\section{Experimental}

\section{General}

All of the chemicals used were of commercial grade and were further purified by recrystallisation and redistilled before use. The solvents used were spectroscopic grade. ${ }^{1} \mathrm{H}$ NMR spectra were obtained by use of BRUKER WM-300 (300MHz). Standard pulse sequences were used for the NMR experiments. Chemical shifts $(\delta)$ are given in ppm and coupling constants $(J)$ in $\mathrm{Hz}$. The IR spectra were obtained on a Thermo Nikolet spectrometer scanning between 4,000-400 $\mathrm{cm}^{-1}$ using $\mathrm{KBr}$ pellets. UV-Vis absorption spectra were measured in CF-26 spectrometer (produced in Russia). Elemental analyses were performed using Heraeus CHNO-Rapid analyzer. Melting points were determined by Electrothermal 9100. Hydrazine hydrate was prepared form hydrazine sulfate and ammonia as described earlier. $^{18}$

For molecular modeling studies, structures were generated with the aid of Chem3D Ultra-9.00 and HyperChem-v.6.02 software. Lone pairs of electrons and hydrogen atoms were added where appropriated. The equilibrium geometries of compounds were located using $\mathrm{MM}+$ (for HyperChem) and MM2 (for Chem3D) functional set. In the next step, RHF calculation (semiempirical AM1 method) were performed and bond length, angles, torsion angles and partial charges have been calculated. Calculations were performed on a $750 \mathrm{MHz}$ Pentium III computer with 256 RAM. 


\section{General procedure of preparation of aldehydes $2 \boldsymbol{a}$ and $\mathbf{2 b}$}

To a stirred solution of $\mathbf{1 a}$ or $\mathbf{1 b}(35 \mathrm{mmol})$ in ethanol $(150 \mathrm{~mL})$ was added the solution of sodium hydroxide $(3.2 \mathrm{~g}, 80 \mathrm{mmol})$ in water $(20 \mathrm{~mL})$. The reaction mixture was heated up to $80{ }^{\circ} \mathrm{C}$. Then, chloroform $(9 \mathrm{~mL}, 0.11$ mol) was added dropwise and the reaction mixture was boiled for a period of 1 hour. The excess of ethanol and chloroform was distilled. Hydrochloric acid was added subsequently until pH 5-6. The residue was dissolved in the minimal amount of diethyl ether and equal amount of saturated solution of $\mathrm{Na}_{2} \mathrm{~S}_{2} \mathrm{O}_{5}$ was added. The mixture was kept for 24 hours and the precipitated solids were filtered off. The solid was dissolved in water and treated with sulfuric acid (10\%). The yellow crystals were obtained by filtration and dried on air.

\section{4,4'-Dihydroxybiphenyl-3,3'-dicarbaldehyde (2a)}

(3.18 g $13.14 \mathrm{mmol}, 45 \%)$; white crystals, mp 260$262{ }^{\circ} \mathrm{C}$; IR $(\mathrm{KBr}) v_{\max } / \mathrm{cm}^{-1}: 3240(\mathrm{OH}), 3069\left(\mathrm{C}_{\mathrm{Ar}}-\mathrm{H}\right), 2820$ (H-CO), 2765 (H-CO), 1705 (H-CO), $1615(\mathrm{C}=\mathrm{C}), 1580$ $(\mathrm{C}=\mathrm{C}), 1513(\mathrm{C}=\mathrm{C}), 1455(\mathrm{C}=\mathrm{C}), 1380(\mathrm{OH}), 1270(\mathrm{C}-$ O), $1210\left(\mathrm{C}_{\mathrm{Ar}}-\mathrm{H}\right), 1150\left(\mathrm{C}_{\mathrm{Ar}}-\mathrm{H}\right), 1030\left(\mathrm{C}_{\mathrm{Ar}}-\mathrm{H}\right), 930\left(\mathrm{C}_{\mathrm{Ar}^{-}}{ }^{-}\right.$ $\mathrm{H}), 890\left(\mathrm{C}_{\mathrm{Ar}}-\mathrm{H}\right), 780\left(\mathrm{C}_{\mathrm{Ar}}-\mathrm{H}\right), 710\left(\mathrm{C}_{\mathrm{Ar}}-\mathrm{H}\right) .{ }^{1} \mathrm{H}$ NMR (DMSO-d ${ }_{6}, 300 \mathrm{MHz}$ ) $\delta 6.98$ (d, J 7.8 Hz, 2H, H-5), 7.86 (s, 2H, H-2), 7.88 (d, J $7.8 \mathrm{~Hz}, 2 \mathrm{H}, \mathrm{H}-6), 9.83$ (s, 2H, $\mathrm{OH}), 10.24$ (s, 2H, H-CO). Analysis Found: C, 69.88; H, 4.10. Calc. for $\mathrm{C}_{14} \mathrm{H}_{10} \mathrm{O}_{4}$ : C, 69.42; $\mathrm{H}, 4.16 \%$.

\section{5,5'-Diamino-4,4'-dihydroxybiphenyl-3,3'-dicarbaldehyde} (2b)

(4.00 g, $14.7 \mathrm{mmol}, 43 \%)$; white crystals, mp 247$250{ }^{\circ} \mathrm{C}$; IR $(\mathrm{KBr}) v_{\max } / \mathrm{cm}^{-1}: 3376\left(\mathrm{NH}_{2}\right), 3305\left(\mathrm{NH}_{2}\right), 3220$ $(\mathrm{OH}), 3010\left(\mathrm{C}_{\mathrm{Ar}}-\mathrm{H}\right), 2810$ (H-CO), 2695 (H-CO), 1695 $(\mathrm{H}-\mathrm{CO}), 1630(\mathrm{C}=\mathrm{C}), 1590(\mathrm{C}=\mathrm{C}), 1470(\mathrm{C}=\mathrm{C}), 1430$ $(\mathrm{C}=\mathrm{C}), 1340(\mathrm{OH}), 1220(\mathrm{C}-\mathrm{O}), 1200\left(\mathrm{C}_{\mathrm{Ar}}-\mathrm{H}\right), 1120\left(\mathrm{C}_{\mathrm{Ar}^{-}}\right.$ $\mathrm{H}), 1010\left(\mathrm{C}_{\mathrm{Ar}} \mathrm{H}\right), 905\left(\mathrm{C}_{\mathrm{Ar}}-\mathrm{H}\right), 860\left(\mathrm{C}_{\mathrm{Ar}}-\mathrm{H}\right), 750\left(\mathrm{C}_{\mathrm{Ar}}-\mathrm{H}\right)$, $705\left(\mathrm{C}_{\mathrm{Ar}}-\mathrm{H}\right) \mathrm{cm}^{-1} .{ }^{1} \mathrm{H}$ NMR (DMSO-d, $\left.300 \mathrm{MHz}\right) \delta 5.85$ (s, 4H, NH $), 6.79$ (s, 2H, H-6), 7.22 (s, 2H, H-3), 9.56 (s, 2H, OH), 10.02 (s, 2H, H-CO). Analysis Found: C, 61.55; $\mathrm{H}, 4.50 ; \mathrm{N}, 10.40$. Calc. for $\mathrm{C}_{14} \mathrm{H}_{12} \mathrm{~N}_{2} \mathrm{O}_{4}$ : C, 61.76; H, 4.44; N, $10.29 \%$.

General procedure of preparation of macrocyclic polyazomethines $\mathbf{3} \boldsymbol{a}$ and $\mathbf{3 b}$

Into the four-necked flask fitted with two dropping funnels, mechanical stirrer and reflux condenser 2-propanol (100 mL) was placed and heated until boiling. The solution of $\mathbf{2 a}$ or $\mathbf{2} \mathbf{b}(1.0 \mathrm{mmol})$ in 2-propanol (10 $\mathrm{mL})$ and freshly obtained hydrazine hydrate $(2.2 \mathrm{mmol}$,
$50 \%)$ were added from different dropping funnels simultaneously for a period of $30 \mathrm{~min}$. The reaction mixture had been heated for 1 hour and precipitated pale yellow crystals were isolated.

\section{Polyazomethine $3 \boldsymbol{a}$}

$(0.27 \mathrm{~g}, 0.58 \mathrm{mmol}, 58 \%)$; yellow crystals, mp 280$282{ }^{\circ} \mathrm{C}$ (isopropanol); UV-Vis (ethanol) $\lambda_{\max } / \mathrm{nm}$ : (loge) 297.8 (3.99), 316.72 (3.56), 329.4 (3.48), 340.7 (3.60), $\mathrm{IR}(\mathrm{KBr}) v_{\max } / \mathrm{cm}^{-1}: 3340(\mathrm{OH}), 3030\left(\mathrm{C}_{\mathrm{Ar}}-\mathrm{H}\right), 2854(\mathrm{H}-$ CO), 1704 (H-CO), $1604(\mathrm{C}=\mathrm{C}), 1457(\mathrm{C}=\mathrm{C}), 1373(\mathrm{C}=\mathrm{N})$, $1295(\mathrm{OH}), 1234(\mathrm{C}-\mathrm{O}), 1172\left(\mathrm{C}_{\mathrm{Ar}}-\mathrm{H}\right), 817\left(\mathrm{C}_{\mathrm{Ar}}-\mathrm{H}\right), 725$ $\left(\mathrm{C}_{\mathrm{Ar}}-\mathrm{H}\right), 509\left(\mathrm{C}_{\mathrm{Ar}}-\mathrm{H}\right) .{ }^{1} \mathrm{H} \mathrm{NMR}\left(\mathrm{CDCl}_{3}, 300 \mathrm{MHz}\right) \delta 6.84$ $\left(\mathrm{d}, J 8.0 \mathrm{~Hz}, 4 \mathrm{H}, \mathrm{C}_{\mathrm{Ar}}-\mathrm{H}\right), 6.88(\mathrm{~s}, 4 \mathrm{H}, \mathrm{H} \mathrm{C}=\mathrm{N}), 7.32(\mathrm{~d}, J$ $\left.8.0 \mathrm{~Hz}, 4 \mathrm{H}, \mathrm{C}_{\mathrm{Ar}}-\mathrm{H}\right), 7.36\left(\mathrm{~s}, 4 \mathrm{H}, \mathrm{C}_{\mathrm{Ar}}-\mathrm{H}\right), 7.96(\mathrm{~s}, 4 \mathrm{H}, \mathrm{OH})$. Analysis Found: C, 70.50; H, 4.28; N, 11.72. Calc. for $\mathrm{C}_{28} \mathrm{H}_{20} \mathrm{~N}_{4} \mathrm{O}_{4}: \mathrm{C}, 70.58 ; \mathrm{H}, 4.23 ; \mathrm{N}, 11.76 \%$.

\section{Polyazomethine $\mathbf{3 b}$}

(0.28 g, $0.53 \mathrm{mmol}, 53 \%)$; yellow crystals, mp 253$255^{\circ} \mathrm{C}$; UV-Vis (ethanol) $\lambda_{\max } / \mathrm{nm}$ : (loge) 300.5 (3.85), 320.5 (3.65), 335.4 (3.35), 345.6 (3.55); IR (KBr) $v_{\max }$ ' $\mathrm{cm}^{-1}: 3370\left(\mathrm{NH}_{2}\right), 3315\left(\mathrm{NH}_{2}\right), 3305(\mathrm{OH}), 3015\left(\mathrm{C}_{\mathrm{Ar}}-\mathrm{H}\right)$, 1600 (C-C), 1435 (C-C), $1355(\mathrm{C}=\mathrm{N}), 1280(\mathrm{OH}), 1230$ (C-O), $1170\left(\mathrm{C}_{\mathrm{Ar}}-\mathrm{H}\right), 815\left(\mathrm{C}_{\mathrm{Ar}}-\mathrm{H}\right), 720\left(\mathrm{C}_{\mathrm{Ar}}-\mathrm{H}\right), 510\left(\mathrm{C}_{\mathrm{Ar}^{-}}{ }^{-}\right.$ H). ${ }^{1} \mathrm{H}$ NMR $\left(\mathrm{CDCl}_{3}, 300 \mathrm{MHz}\right) \delta 5.83\left(\mathrm{~s}, 8 \mathrm{H}, \mathrm{NH}_{2}\right), 6.79$ (s, 4H, C $\left.\mathrm{Ar}^{-\mathrm{H}}\right), 6.85(\mathrm{~s}, 4 \mathrm{H}, \mathrm{H} \mathrm{C}=\mathrm{N}), 7.22\left(\mathrm{~s}, 4 \mathrm{H}, \mathrm{C}_{\mathrm{Ar}}-\mathrm{H}\right)$, 7.92 (s, 4H, OH). Analysis Found: C, 62.60; H, 4.50; N, 20.92. Calc. for $\mathrm{C}_{28} \mathrm{H}_{24} \mathrm{~N}_{8} \mathrm{O}_{4}$ : C, 62.68; H, 4.51; N, 20.88\%.

\section{Polyazomethine 4}

To a solution on the macrocyclic polyazomethine $\mathbf{3 a}$ $(1.8 \mathrm{~g}, 3.78 \mathrm{mmol})$ in ethanol $(60 \mathrm{~mL})$ stirred at $30{ }^{\circ} \mathrm{C}$ was added bromine $(22.68 \mathrm{mmol})$ dropwise. The temperature was maintained at $30-32{ }^{\circ} \mathrm{C}$ for a period of 45 min after complete addition of bromine. The reaction mixture was cooled up to room temperature and filtered off. The solid was washed with hot water and ethanol. (2.39 g, $3.01 \mathrm{mmol}, 80 \%)$; yellow crystals, mp 113$115^{\circ} \mathrm{C}$; IR $(\mathrm{KBr}) v_{\max } / \mathrm{cm}^{-1}: 3350(\mathrm{OH}), 3020\left(\mathrm{C}_{\mathrm{Ar}}-\mathrm{H}\right), 1600$ $\left(\mathrm{C}_{\mathrm{Ar}}=\mathrm{C}_{\mathrm{Ar}}\right), 1450\left(\mathrm{C}_{\mathrm{Ar}}=\mathrm{C}_{\mathrm{Ar}}\right), 1380(\mathrm{C}=\mathrm{N}), 1290(\mathrm{OH}), 1240$ (C-O), 580 (Br). Analysis Found: C, 42.50; H, 2.10; Br, 40.30; N, 7.00. Calc. for $\mathrm{C}_{28} \mathrm{H}_{16} \mathrm{Br}_{4} \mathrm{~N}_{4} \mathrm{O}_{4}$ : C, 42.46; H, 2.04; $\mathrm{Br}, 40.35 ; \mathrm{N}, 7.07 \%$.

\section{Polyazomethine 5}

To a solution of polyazomethine $3 \mathbf{a}(0.5 \mathrm{~g}, 1.05 \mathrm{mmol})$ in DMF (45 mL) stirred at $20^{\circ} \mathrm{C}$ was added $\mathrm{POCl}_{3}(6.3$ mmol) dropwise for a period of 2 hours. Reaction mixture was heated up to $80^{\circ} \mathrm{C}$ until complete conversion of $\mathbf{3 a}$ (approximately 3 hours). The progress of the reaction 
monitored by TLC (eluent toluene/ethylacetate 2:1 (v/v)). The precipitated resinous residue was filtered off, washed with ethanol and purified via bisulphite derivative. For this aim, obtained resinous residue was dissolved in saturated solution of $\mathrm{Na}_{2} \mathrm{~S}_{2} \mathrm{O}_{5}$ and re-precipitated with treatment of diluted $(20 \%)$ sulfuric acid. $(0.43 \mathrm{~g}, 0.735$ mmol, $70 \%$ ); yellow crystals, mp $119-120{ }^{\circ} \mathrm{C}$; IR (KBr) $\mathrm{v}_{\max } / \mathrm{cm}^{-1}: 3330(\mathrm{OH}), 3010\left(\mathrm{C}_{\mathrm{Ar}}-\mathrm{H}\right), 2850(\mathrm{H}-\mathrm{CO}), 1710$ $(\mathrm{H}-\mathrm{CO}), 1600\left(\mathrm{C}_{\mathrm{Ar}}=\mathrm{C}_{\mathrm{Ar}}\right), 1375(\mathrm{C}=\mathrm{N}), 1230(\mathrm{C}-\mathrm{O})$. Analysis Found: C, 65.30; H, 3.40; N, 9.55. Calc. for $\mathrm{C}_{32} \mathrm{H}_{20} \mathrm{~N}_{4} \mathrm{O}_{8}: \mathrm{C}, 65.31 ; \mathrm{H}, 3.43 ; \mathrm{N}, 9.52 \%$.

\section{Results and Discussion}

The polyazomethines $\mathbf{3} \mathbf{a}$ and $\mathbf{3 b}$ were obtained in two steps from 4,4'- dihydroxybiphenyl and 5,5'-diamino-4,4'dihydroxybiphenyl, respectively, according to the Scheme 1.

Aldehydes 2a,b have been prepared under various conditions. The successful result has been obtained when reaction has been carried out in ethanol under ReimerTiemann conditions. The crude products $\mathbf{2 a}, \mathbf{b}$ are lightbrown solids. The multiple recrystallizations in the various solvents or solvent mixtures do not result in purification of product. The satisfactory purity may be achieved by purification via corresponding bisulphite derivatives.

Melting points of 2a,b after purification are 260-262 and $247-250{ }^{\circ} \mathrm{C}$ respectively. The yields were approximately $43-45 \%$.

The formation of carbonyl compounds $\mathbf{2} \mathbf{a}$ and $\mathbf{2} \mathbf{b}$ is confirmed by various methods. $\mathbf{2 a}$ and $\mathbf{2} \mathbf{b}$ reacts with Tollens' reagent with formation of silver. IR spectrum shows absorption bands on 2820-2810 and 1705-1695 $\mathrm{cm}^{-1}$, characterizing $\mathrm{C}-\mathrm{H}$ (aldehyde) and $\mathrm{C}=\mathrm{O}$ bonds, respectively. In addition the ${ }^{1} \mathrm{H}-\mathrm{NMR}$ data are in good agreement with the above mentioned results. Namely, ${ }^{1} \mathrm{H}-\mathrm{NMR}$ spectra of $\mathbf{2 a}$ showed only six aromatic protons, represented as two doublets and one singlet. The ${ }^{1} \mathrm{H}$ NMR data of $\mathbf{2 b}$ involve signals of four aromatic protons. The appearance of singlet at $\delta 10.24$ for $\mathbf{2 a}$ and at $\delta 10.02$ for $\mathbf{2} \mathbf{b}$ indicates to formation of carbonyl compounds.

Condensation reactions between $\mathbf{2 a , b}$ and freshly synthesized hydrazine hydrate have been carried out under high-dilution. The reacting agents $\mathbf{2} \mathbf{a}, \mathbf{b}$ as isopropanol solutions and hydrazine hydrate were added to isopropanol drop-wise simultaneously from two different droppingfunnels. Products $\mathbf{3 a}$ and $\mathbf{3 b}$ have been isolated, after boiling the reaction mixture for a period of approximately $1 \mathrm{~h}$, as yellow crystals with the yield up to $53-58 \%$.

The formation of desired products is established with UV-Vis, IR and ${ }^{1} \mathrm{H}-\mathrm{NMR}$ spectroscopy. UV-Vis spectra of $\mathbf{3} \mathbf{a}$ and $\mathbf{3 b}$ contain multiple bands in the near-UV range, while starting compounds $\mathbf{2} \mathbf{a}$ and $\mathbf{2 b}$ have no absorption bands in this range (Figure 1). It should be noted, that multiple absorption bands are characteristic for azomethine compounds. The long wave absorption band of $\mathbf{3 b}$ undergoes bathochromic shift for $5 \mathrm{~nm}$ because of influence of conjugated substituents (amino groups). The above described observation has been confirmed by results of the CNDO/S semi-empirical studies of $\mathbf{3 a}$ and $\mathbf{3 b}$.

In the IR spectrum of $\mathbf{3 a}$ the disappearance of absorption bands at 2820, 2765 and $1705 \mathrm{~cm}^{-1}$ and formation of new absorption band at $1373 \mathrm{~cm}^{-1}$ indicates the conversion of aldehyde group into azomethine one. ${ }^{1} \mathrm{H}-\mathrm{NMR}$ spectrum of $\mathbf{3 a}$ displays five signals, represented as 2 doublets and 3 singlets. The absence of the low-field signal $(\delta 10.24)$ and the new signal, that appears at $\delta 6.88$ point to successful reaction. Similarly, IR spectrum of $\mathbf{3 b}$ contains absorption band at $1355 \mathrm{~cm}^{-1}$ and ${ }^{1} \mathrm{H}-\mathrm{NMR}$ spectrum-chemical shift at $\delta 6.85$, that corresponds to $\mathrm{N}=\mathrm{CH}$ group.

Polyazomethine dye 3a may be converted into the interesting polyazomethine pigments $\mathbf{4}$ and $\mathbf{5}$ according to the Scheme 2.

The treatment of the ethanol solution of $\mathbf{3 a}$ with bromine at $30{ }^{\circ} \mathrm{C}$ gives macrocyclic polyazomethine pigment 4 . The pigment 5 has been obtained according to Vilsmeier reaction. The solution of $\mathbf{3 a}$ in DMF under the

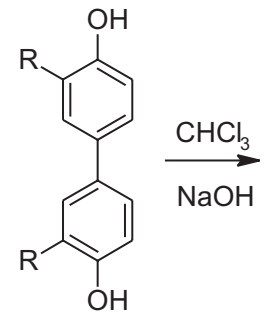

$1 a, b$<smiles>[R]c1cc(-c2cc([R])c(O)c(C=O)c2)cc(C=O)c1O</smiles>

2a,b<smiles>[R]c1cc(-c2cc([R])c(O)c(/C=N/N=C/c3cc(/C=N/N=C/c4cc(-c5cc([R])c(O)c(O)c5)cc([R])c4O)cc(-c4cc([R])c(O)c(C)c4)c3)c2)cc([R])c1O</smiles>

$3 a, b$

a, $\mathrm{R}=\mathrm{H} ; \quad$ b, $\mathrm{R}=\mathrm{NH}_{2}$

Scheme 1. Synthesis of macrocyclic azomethines $\mathbf{3 a}$ and $\mathbf{3 b}$ 


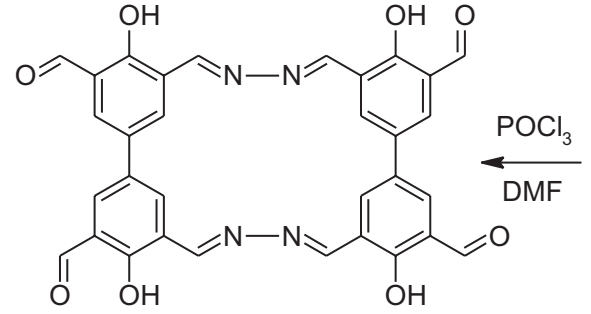

Scheme 2. Synthesis of macrocyclic azomethine pigments $\mathbf{4}$ and $\mathbf{5}$

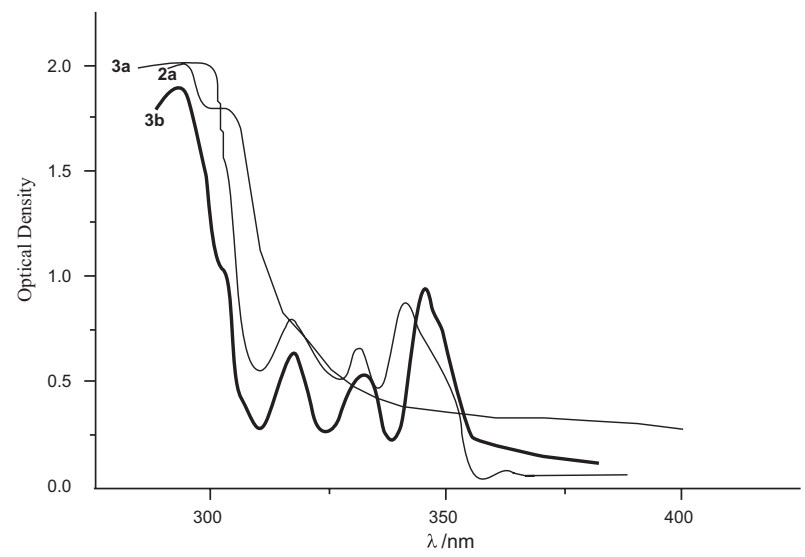

Figure 1. UV-Vis spectra of $\mathbf{2 a}, \mathbf{3 a}$ and $\mathbf{3 b}$.

action of $\mathrm{POCl}_{3}$ yields yellow pigment 5. Unexpectedly, compounds $\mathbf{4}$ and $\mathbf{5}$ are insoluble in most organic and inorganic solvents. For example, all our attempts to dissolve these compounds into the solvents such as methanol, ethanol, isopropanol, toluene, benzene, xylenes, DMF, chloroform, hexane, ethyl acetate, concentrated sulfuric acid and water solution of sodium hydroxide was unsuccessful. For this reason, unfortunately, the spectral investigation has not been carried out.

The elemental analysis of $\mathbf{4}$ and $\mathbf{5}$ showed that proposed compounds contained four bromine atom and aldehyde group, respectively. In addition, the presence of aldehyde group is established by successful reaction with Tollen's reagent.

The location of the functional groups was suggested upon the base charge-distribution in 3a, calculated by AM1 semi-empirical method. The most negative charge is located on the ortho-carbon atom from carbon atom bonded to hydroxyl.

The macrocyclic polyazomethine dyes $\mathbf{3} \mathbf{a}$ and $\mathbf{3 b}$ as well as macrocyclic polyazomethine pigments $\mathbf{4}$ and $\mathbf{5}$ present well pronounced fluorescent property in solid state (magenta luminescence under UV-light exposure).

\section{Quantum-chemical calculation}

Interesting data were obtained from quantum-chemical<smiles>Oc1c(Br)cc(/C=N/N=C/c2cc(Br)cc(-c3cc(Br)c(O)c(/C=N/N=C/c4cc(-c5cc(Br)c(O)c(Br)c5)cc(Br)c4O)c3)c2)cc1Br</smiles>

calculations of these macrocyclic compounds. Optimized models of structures are rather "thin" molecules. The thickness of molecules does not exceed 3.56 A. Hydrogen of the $\mathrm{CH}=\mathrm{N}$ groups is oriented out of cycle hole. The macrocycle hole diameter is up to $4.2-4.33 \AA$ (Figure 2). We suggest, that such wide hole will allows to form stable complex compounds with ions of large size and this complexation is, currently, under investigation.

Charge distribution among the cycle forming atoms vary from -0.138 to +0.138 . The irregularity of charge distribution provides to generate dipole moment with the value of 3.352D and 1.977D for $\mathbf{3 a}$ and $\mathbf{3 b}$ respectively. The vector of dipole moment is positioned in the "crown" center and directed at right angle to plane of molecule.

It must be noted that the open chair azomethines have greater dipole moment than $\mathbf{3 a}$ and $\mathbf{3 b}$. Additionally, introduction of strong electron-releasing amino groups causes dipole moment decrease.

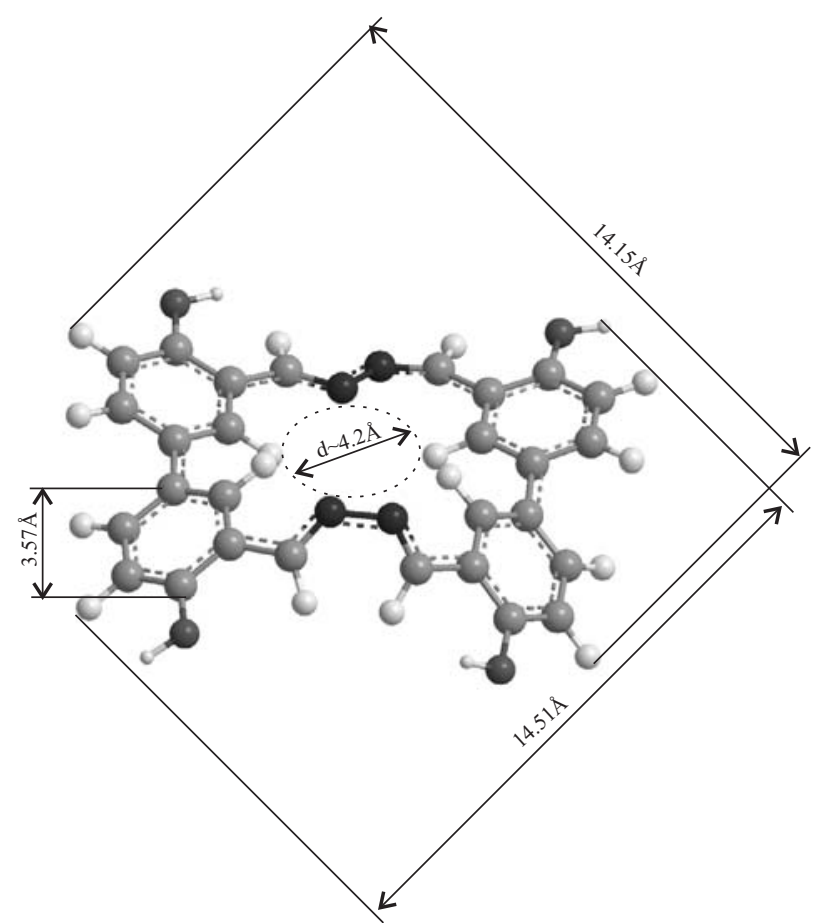

Figure 2. Optimized structure model of macrocyclic azomethine $\mathbf{3 a}$. 


\section{Conclusion}

In summary it has been described the method of the synthesis of 20 -membered cyclic polyazomethines compounds according to two step conversion, containing carbonylation and condensation reaction with hydrazine hydrate. Both reactions may be carried out under rather simple routines with moderate yields. In addition, the synthesized macrocyclic polyazomethines may undergo various electrophilic substitution reactions, giving valuable macrocyclic polyazomethine pigments.

The desired products are characterized with well pronounced fluorescent properties in the solid state. Amino groups presented in $\mathbf{3 b}$ may be used for further conversions into novel macrocyclic azomethine compounds, which is under current study.

\section{Acknowledgments}

The authors thank Prof. V. Traven', head of the department of organic chemistry, Russian University of Chemical Technology, for providing ${ }^{1} \mathrm{H}-\mathrm{NMR}$ spectra during the investigation.

\section{References}

1. Jarrahpour, A. A.; Motamedifar, M.; Pakshir, K.; Hadi, N.; Zarei, M.; Molecules 2004, 9, 815.

2. More, P. G.; Bhalvankar, R. B.; Pattar, S. C.; J. Indian Chem. Soc. 2001, 78, 474.

3. El-Masry, A. H.; Fahmy, H.H.; Abdelwahed, S.H.A.; Molecules 2000, 5, 1429.

4. Baseer, M. A.; Jadhav, V. D.; Phule, R. M.; Archana, Y. V.; Vibhute, Y. B.; Orient. J. Chem. 2000, 16, 553.
5. Pandeya, S. N.; Sriram, D.; Nath, G.; De Clercq, E.; Il Farmaco 1999, 54, 624.

6. Singh, W. M.; Dash, B. C.; Pesticides 1988, 22, 33.

7. Hodnett, E. M.; Dunn, W.; J. Med. Chem. 1970, 13, 768.

8. Desai, S. B.; Desai, P. B.; Desai, K.R.; Heterocycl. Commun. 2001, 7, 83 .

9. Pathak, P.; Jolly, V. S.; Sharma, K. P.; Orient. J. Chem. 2000, 16,161

10. Samadhiya, S.; Halve, A.; Orient. J. Chem. 2001, 17, 119.

11. Taggi, A. E.; Hazef, A. M.; Wack, H.; Young, B.; Ferraris, D.; Lectka, T.; J. Am. Chem. Soc. 2002, 124, 6626.

12. Aydogan, F.; Öcal, N.; Turgut, Z.; Yolacan, C.; Bull. Korean Chem. Soc. 2001, 22, 476.

13. Khandar, A. A.; Nejati, K.; Rezvani, Z.; Molecules 2005, 10, 302.

14. Busch, D. H.; Alcock, N. W.; Chem. Rev. 1994, 94, 585.

15. Zhoua, H.; Lia, D.; Wanga, P.; Chenga, L.: Gaoa, Y.; Zhua, Y.; Wua, J.; Tiana, Y.; Taob, X.; Jiangb M.; Fund, H-K.; J. Mol. Struct. 2007, 826, 205.

16. Rajendran, G.; Abhilasha, A.; Asian J. Chem. 2007, 19, 1202.

17. Kaya, Ý.; Koyuncua, S.; Penola, D.; Eur. Polym. J. 2006, 42, 3140.

18. Krasovitskii, B. M.; Fediuniaeva, I. A.; Shakhrovich, A. L.; J. Org. Chem. (Russia) 1988, 24, 1302.

19. Argyropoulos, N. G.; Sarli, V. C.; Gdaniec, M.; Eur. J. Org. Chem. 2006, 16, 3738.

20. Wessjohann, L.A.; Ruijter, E.; Garcia-Rivera, D.; Brandt, W.; Mol. Diversity 2005, 9, 171.

21. Coldham, I.; Dobsona, B.C.; Franklina, A.I.; Fletcherb, S.R.; Tetrahedron Lett. 2007, 48, 873.

21. Hayvali, Z.; Haivali, M.; Dal, H.; Molecules 2004, 9, 860.

22. Koriakin, I.V.; Angelov I.I.; Pure Chemical Compounds, Khimia: Moscow, 1974, p. 91.

Received: January 30, 2007

Web Release Date: October 4, 2007 